\title{
Prospective Study of Crowdfunding
}

\section{KORCHI Mohamed Amine ${ }^{1}$ and EL ASSALI Ayoub ${ }^{2}$}

1 Research Team in Finance and Accounting Management,

2 Research Team in Entrepreneurship and Public Policies, Faculty of Economic and Social Legal Sciences Kénitra,

Maamora University Campus BP: 2010,

Kenitra, Morocco

\begin{abstract}
This article aims to promote the mobilization of investments of the Moroccan ethnicity in the field of innovative entrepreneurship to serve the sustainable and inclusive development of their territories of origin through crowdfunding or "solidarity financing".
\end{abstract}

Key words: Crowdfunding, Startup, Investment.

\section{INTRODUCTION}

A prospective study aims at defining the different possible evolutions of a given system (which could be an institution, a phenomenon, a particular domain, etc.) starting from a present state. It is natural then to define three moments (the chronological order will be discussed later) for the study:

- The present.

- The future.

- $\quad$ Paths from the Present to the Future.

\section{RESEARCH METHODOLOGY}

The study of the present is important to know the initial situation and to define the actions to be undertaken in order to reach the possible future. This study is also very important in determining the elements of the dynamics that could shape the future.

It is also important to study the present to grasp what is essential that justifies the exploration of the future. Because, even if the prospective offers the possibility of embracing several problems at once, there will always be a problem to privilege. The study of the present implies that one seeks to know what are the stakes, the challenges, the opportunities, etc. facing the system or phenomenon studied. It is also necessary to be able to have the elements of dynamics, of the motricity of the system. To better understand the present, we must identify the factors that are important for the future. It is also necessary to know how these factors will play on each other and in which directions. Of course, one can get help from specialists on the subject. However, it is often necessary to use the past of the system to know its dynamics and to learn lessons about the future. In this way, we add to the three preceding moments a dimension of retrospective study.

In addition to the elements of internal dynamics, the analysis of the present should take into account the system environment that could influence its future. It is thus a set of factors of changes and parameters that should not only be identified but also in determining the possible evolution and the interactions. It is only from here that one can make visions about the future of the whole system or phenomenon and that scenarios can be defined. Once the scenarios are well identified, they should be evaluated and a strategy defined that achieves what is desirable and avoids what is undesirable. We have just added to the previous moments, two other components: evaluation and strategy.

The conduct of a prospective study will then be composed of the following clusters:

- Retrospective.

- Present (study of the issues, internal and external factors of the dynamics of the system)

- Future.

- Evaluation and choice.

- Paths

- Strategy. 
The diagram above provides a representation of these different moments of a prospective study.

\section{Figure 1: Conducting a prospective study}

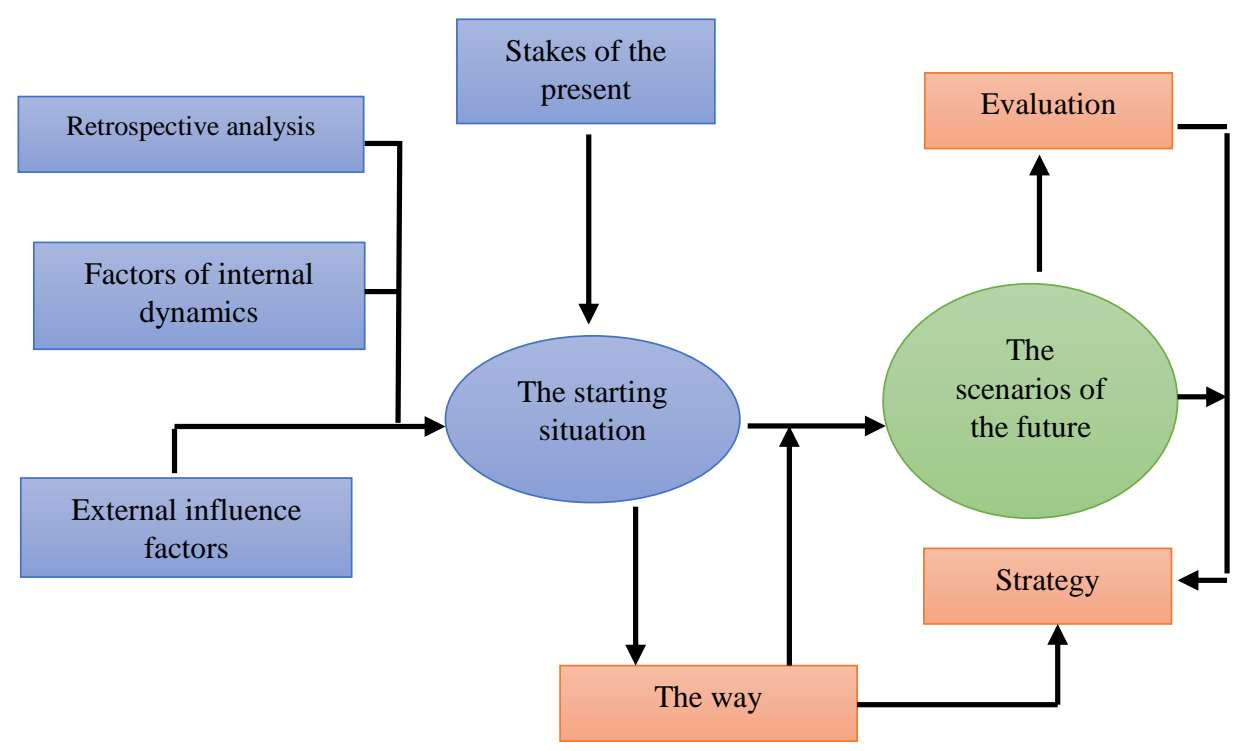

Source: Developed by the author using a thorough reading of the prospective method

\section{State of play:}

The state of play focused on both the literature review on the topic of crowdfunding and the identification of existing initiatives in collaborative financing.

The contextual analysis was articulated around the main texts dealing with the institutional and legislative framework in Morocco, notably in:

- Call for public generosity (Law 004-71),

- $\quad$ Public offerings (Law 44-12)

- $\quad$ Bank Accreditation for the collection of funds for third parties that is issued by the Central Bank, (BAM)

- Exchange Office legislation for transfers from abroad.

The contextual bibliography also made it possible to analyze the nature of the investments of the ethnic group and its potential for the development of Morocco.

This analysis has highlighted the opportunities offered by crowdfunding as an innovative and relevant approach given the strong growth of the digital sector that the

Morocco through the development of $4 \mathrm{G}$ internet, mobile telephony, social networks and electronic banking.

In order to have an overview of the crowdfunding ecosystem and its link with the ethnic group, a number of actors from different institutions were met. The main actors encountered include :

- Ministries and national institutions :

- The Ministry of Moroccans Residing Abroad and Migration Affairs (MCMREAM) in charge of the National Strategy of Moroccans of the World (MDM) having as one of the strategic objectives the contribution of MDM to the development of the country.

- The Ministry of Finance through the Directorate of the Treasury and External Finance, in charge of drafting the bill on crowdfunding;

- $\quad$ The Hassan II Foundation for MRE.

- The institutions of management and regulation of the financial sector Bank Al Maghreb (BAM), the Moroccan Authority of the Market of the Capital (AMMC), the Office of the Changes.

- The private sector and civil society: banks, law firms, associations working with ethnic groups (development or entrepreneurship), Business-Angel crowdfunding platforms, Hub Africa (entrepreneurship in Africa).

In parallel, a survey was sent to a part of the ethnic group, in order to better understand the interest of the ethnic group for crowdfunding, which aims to allow us to identify a general trend. This one deserves to be supported by a better sampling, the organization of focus group to reach the greatest number. This survey could be taken again through the crossing points (port, airport, border posts) of the ethnic group during the summer period. The means of the study did not allow us to undertake such an activity. 
Finally, an active participation in the Hub Africa forum organized in Casablanca helped consolidate this mapping. This forum not only dealt with the various economic, financial and regulatory aspects related to the promotion of crowdfunding in the countries of the region, but also the mobilization of the ethnic group for the benefit of the development of the countries of origin through the crowdfunding platforms.

Table 1: Distribution of MRE by geographical area of residence

\begin{tabular}{|l|l|l|}
\hline \multicolumn{1}{|c|}{ Choice of answers } & \multicolumn{1}{|c|}{ Replie } & \\
\hline Europe & $76.92 \%$ & 50 \\
\hline North America & $12.31 \%$ & 8 \\
\hline Latin America & $1.54 \%$ & 1 \\
\hline Asia & $1.54 \%$ & 1 \\
\hline Africa & $7.69 \%$ & 5 \\
\hline Oceania & $0.00 \%$ & 0 \\
\hline Other & $0.00 \%$ & 0 \\
\hline Total & & 65 \\
\hline
\end{tabular}

Source : http// : www.marocainsdumonde.gov.ma/

Table 2: Distribution of MRE by country of residence

\begin{tabular}{|l|l|l|}
\hline \multicolumn{1}{|c|}{ Choice of answers } & \multicolumn{1}{|c|}{ Replie } & \\
\hline Germany & $2.90 \%$ & 2 \\
\hline Belgium & $7.25 \%$ & 5 \\
\hline Spain & $2.90 \%$ & 2 \\
\hline France & $52.17 \%$ & 36 \\
\hline Italy & $1.45 \%$ & 1 \\
\hline Netherlands & $2.90 \%$ & 2 \\
\hline Britain & $7.25 \%$ & 5 \\
\hline Sweden & $1.45 \%$ & 1 \\
\hline Swiss & $0.00 \%$ & 0 \\
\hline USA & $10.14 \%$ & 7 \\
\hline Canada & $2.90 \%$ & 2 \\
\hline Other & $8.70 \%$ & 6 \\
\hline & & 69 \\
\hline
\end{tabular}

Source : http// : www.marocainsdumonde.gov.ma/

\section{1- Ethnicity and crowdfunding development in Morocco}

This section will allow us to address the role of ethnicity in the development of crowdfunding and to better understand the link that brings them together, from a Co-development perspective "migration and development".

Ethnicity has undeniable capital (human, social, cultural and economic) to be a major player in the development of crowdfunding. The Moroccan ethnicity living mainly in Europe is familiar and sensitive to this type of financing, unlike the local Moroccan population.

The development of crowdfunding in Morocco will require financial education, extension campaigns that will take time before the concept is adopted by the local population. This in itself may slow down its development.

Ethnicity, with its knowledge of the tool and its risk culture, can constitute a target group in the early stages of crowdfunding development and allow the emergence of good practices that will promote its development.

In this same part of the study we will discuss the interest of the ethnic group to engage in entrepreneurship in Morocco and the constraints related to the financing of installed startups.

The study will comprehensively address the regulatory framework specific to each crowdfunding practice to understand the complexity of legislation and a benchmarking practices in the United States and France. These insights will allow us to propose a certain number of recommendations to the attention of the various actors of crowdfunding.

\subsubsection{Ethnic and crowdfunding}

\section{a. Link between ethnicity and crowdfunding}

There is no universally accepted definition of ethnicity. We will therefore use the definition proposed in the manual "How to involve ethnic groups in development: a handbook for policymakers and practitioners in countries of origin and host countries", written by IOM and the Migration Policy Institute. 2012 to know: 
"Emigrants and their offspring who live outside their home country or the country of their parents, on a temporary or permanent basis, while maintaining emotional and material links with their country of origin. "

Moroccan migration today concerns more than 100 countries and represents $10 \%$ of the total Moroccan population. The Moroccans of the world, reside mainly in the European countries, Arab or North America and maintain privileged cultural and economic links with their country of origin. The term "ethnicity" makes it possible to give an account of the different links existing between the Moroccans of the world and their country of origin or that of their parents. Belonging to an ethnic group implies a consciousness, a bond of affection and belonging often claimed.

Morocco has been a pioneer country for maintaining and strengthening ties with its ethnic group. It was one of the first countries in the region to recognize the contribution of its nationals living abroad (MRE) in the development and outreach of Morocco. The fact of having another nationality for an MRE has not been a hindrance to the development of public policies targeting ethnic groups. There are many public institutions dedicated to Moroccans in the world including: The Ministry of Moroccans Residing Abroad and Migration Affairs (MCMREAM), the Hassan II Foundation for Moroccans Residing Abroad, the Council of the Moroccan Community Abroad (CCME) and the Department of Consular and Social Affairs of the Ministry of Foreign Affairs and Cooperation (DACS - MAEC).

According to the 2015 World Bank Remittance Report, Morocco remains among the countries that benefit the most from foreign currency transfers of its ethnic group, with a total of 6.4 billions dollars, or about 62 billion dirhams sent by MRE (Moroccans residing abroad). This contribution represents $7 \%$ of the Kingdom's Gross Domestic Product (GDP).

This report from the World Bank gives a history of the inflow of foreign currencies in different countries of the world, since 1970. This retrospective highlight that the transfer of currency to Morocco by the MRE are twelve times higher today, that 40 years ago. A finding that can be explained by the increase in Moroccan migration in recent decades.

However, the link with the country of origin can not be limited to currency transfers, however important it is hence the need to adapt a broader vision that can be reflected in the paradigm "migration and development".

As part of the program of the Joint Initiative on Migration and Development (JMDI), and in particular in its document entitled "Migration and Development: A bottom-up approach - A manual for practitioners and policymakers", it has been clarified that human mobility creates a number of "capitals". These assets are resources that can also contribute to the development of the country of origin. It is social, financial, human and cultural capital.

Crowdfunding is a real opportunity for the ethnic group to contribute to the development of the country of origin while mobilizing its various "capitals".

The migrant can both be a project leader via a crowdfunding platform, financial contributor of a project or initiator of a platform. There is some concomitance between the crowdfunding philosophy and the mobilization of migrants' capital for development.

As a project leader, the migrant emphasizes his competence, his acquired expertise and his network in a project that is economic, social or cultural.

Indeed, crowdfunding uses "love money" and responds to the emotional dimension sought by the ethnic group in its commitment to a development project.

\section{b. Main characteristics of the Moroccan ethnicity:}

Moroccan migration is characterized by its seniority, indeed the first waves of immigration to Europe are prior to the period of the French protectorate. Quotas of Moroccans are raised for the two world conflicts to participate in the war effort both in the arms industry and to intervene on the various fronts of the Second World War than in the operations of the colonial army (Indochina ... etc.) The reconstruction of post-war Europe will require manpower and see significant migration flows from Morocco. During the 1960s, agreements were concluded between Morocco and four European countries, including Belgium, France, Germany and the Netherlands to regulate the flow of Moroccan migrants.

In the 1980s, Moroccan migration will move towards other countries and other continents.

The Ministry of Moroccans Residing Abroad and Migration Affairs (MCMREAM) defines ethnicity as people who have kept a direct or indirect link with Morocco, participating or not in the life of the Moroccan community out of its borders, and belonging to the first, second, third, nth generation of emigrants in another country.

In the 2015 edition of the MRE guide published by MCMREAM, the ethnic group is estimated at 3.8 millions MRE in the world (2014 figures). It remains concentrated between Europe and the Arab countries (respectively $86 \%$ and 88 of the total MRE in the world). 
Table 3: Distribution of MRE in the world

\begin{tabular}{|c|c|c|}
\hline & Number of MRE & $\% \mathrm{MRE}$ \\
\hline Europe & 2837654 & 86,09 \\
\hline France & 1331400 & \\
\hline Spain & 758000 & \\
\hline Italy & 506000 & \\
\hline Netherlands & 460000 & \\
\hline Belgium & 407647 & \\
\hline Arab countries & 281631 & 8,54 \\
\hline America & 161276 & 4,89 \\
\hline United States & 150000 & \\
\hline Canada & 120000 & \\
\hline Africa & 11675 & $\mathbf{0 , 3 5}$ \\
\hline Asia & 3686 & $\mathbf{0 , 1 1}$ \\
\hline Oceania & 351 & $\mathbf{0 , 0 1}$ \\
\hline Total MRE & 3296273 & 100 \\
\hline
\end{tabular}

Source : MCMREAM MRE Guide 2015

In this guide we find, the Moroccans of France in first position with more than 1.3 million people followed by Moroccans from Israel (800,000 peoples). Then come those from Spain (758,000 peoples) and Italy (506,000 peoples).

\section{1.2. Crowdfunding and entrepreneurship in Morocco}

The crowdfunding, the need for financing and the ecosystem have already been defined in general for the world in the second chapter, we will present them in speaking of the Moroccan case.

\section{a. The need for startups financing}

The difficulties to obtain bank financing, especially for startups, are the subject of frequent and intense debates in Morocco. Moroccan startups say "generally having trouble getting the credit they need to create or grow."

Yet, the politics and promotion of startups are strategic pillars for growth, economic and employment. Although business start-ups are steadily increasing in Morocco and reflect the impact of reforms initiated in Morocco, the startup sector suffers from structural weaknesses in terms of competitiveness, productivity, capitalization and informality. The challenges identified concern, in particular, access to finance for these enterprises, which is central to the development of the economy and the growth dynamic. In fact, startups constitute in a market economy the basis of the productive fabric and actively participate in the development and creation of wealth and employment.

\section{b. The financial ecosystem and crowdfunding}

- Crowdfunding and banks :

The Moroccan banking sector must diversify and develop its currently uncompetitive financing offers. Similarly, banking services are still too few in areas where the rate of banking remains too low.

On the one hand, companies complain about banks' risk aversion and their lack of interest in financing startups. On the other hand, the banks argue that they try to develop their startup portfolios, but that the quality of credit applications and the lack of transparency of companies, limit the number of bankable projects available to them. It is therefore a question of restoring trust between the two parties and modifying perceptions on both sides. Crowdfunding presents itself as a real opportunity by acting as a bridge between the formalization of corporate financing and a banking system considered excessive by some small entrepreneurs. The analysis of data from the Investment Climate Assessment (ICA) shows that $53.4 \%$ of companies did not use bank credit for their most recent investments compared to $46.6 \%$ who asked for it and who got it. In order to assess the extent of the problems of access to finance, it is necessary to estimate what is the proportion of companies currently held off the credit market, compared to the one that has opted not to seek Bank loan.

- Crowdfunding and microcredit :

The model of solidarity loan (without interest) is a perfect example of complementarity between crowdfunding and microcredit. Instead of the Micro Finance Institution (MFI) resorting to banks to finance itself at high interest rates in order to be able to grant microloans, they are moving micro-entrepreneurs' projects back to the crowd-appealing platform. This system enables MFIs to 
find a low-cost resource and the platform to benefit from the institution's proximity to field operators through its local presence. It also enables beneficiaries to develop a low-cost income-generating activity by providing visibility on the web to a population that does not always know how to read and write. The crowdfunding allows a very low-cost fund raising in several countries and offers MFIs the possibility of lowering the interest rates applied to the beneficiaries and thus having an action focused on its social impact by contributing to the development of the social economy and solidarity.

\section{- Crowdfunding and Islamic finance}

The crowdfunding and the Islamic finance are based on the same principles, namely the infatuation with which the latter in Morocco the development of Islamic platforms constitute a buoyant market. While the new law on Islamic finance in Morocco is quite recent, the first approvals are already under consideration and a first authorization to participate in the capital of an Islamic bank has been issued to a commercial bank of the place. Banks will be the first to grab this market will probably follow the financial companies, investment banks and payment companies as many actors who could as well position themselves on the crowdfunding and why not on a combination of two models. Crowdfunding is perfectly compatible with the principles of Islamic finance, since they share common principles such as risk sharing and benefit-sharing.

\section{- Crowdfunding and Angel business}

Capital investment is in Morocco still too little developed for startups and start-ups, despite the launch of several funds and a network of business Angel that are still struggling to hatch.

In July 2016, the Minister of Economy and Finance chaired the launch ceremony of the "INNOV INVEST FUND" intended to finance the start-up of startups and innovation, which will be entrusted to the Caisse Centrale de Garantie (CCG), a public agency specializing in the financing of startups. The fund is expected to benefit from a $\$ 50$ millions loan from the World Bank. Financing start-ups early in life (seed) remains the primary goal, but the CGC plans to add debt financing to equity investments offered by the World Bank.

\section{- Crowdfunding and risk sharing}

The use of crowdfunding, which covers part of the risk associated with a credit transaction, or a stake in the capital, could contribute to its lightening and thus compensate for the financial institutions' reluctance regarding certain projects.

Crowdfunding from this point of view could be a complementary model of attractive financing for project promoters. It is therefore a question of remedying this lack of liquidity of the markets whose financing offer remains too little diversified and poorly adapted to the Moroccan startup. The reluctance of banks to risk generated by the startup could be offset by a reallocation of financial flows and risk pooling as proposed by crowdfunding.

Project leaders, who find a financing alternative in the crowdfunding that includes risk pooling, are likely to also represent secondarily for financial institutions a pool of potential clients-entrepreneurs with proven track record, interesting for banking institutions.

\section{3 - CROWDFUNDING AND LEGISLATION IN MOROCCO}

In this section we will see the regulatory framework as well as the banking law, public savings, the call for generosity, international financial flows, the two French and American models and a little reflection on the draft law in the appendix.

\subsection{Regulatory framework}

Regardless of the model adopted, platforms must respect the regulatory obligations that derive from their status and activity: fundraising, custody and transfer of funds, provision of means of payment and bank intermediation.

The current Moroccan legal framework requires an adaptation of the different regulations with which crowdfunding could be in contradiction. This legal and regulatory framework could be identified in the following texts:

- Public call to the Savings: Dahir 1-12-55 carrying the law n ${ }^{\circ} 44-12$ of December 28, 2012 relating to the public call to the savings and the information required of the legal entities and organizations making public appeal to the savings and Dahir carrying law $n{ }^{\circ} 11-93-212$ of September 21 st, 1993 relating to the ethical council of the securities and to the information required of the legal persons making public call to the saving

- Private Placement Procedure (AMMC): Dahir 1-12-55 Law No. 44-12 of 28 December 2012 on the public offering and the information required of legal entities and public bodies savings and provisions of the circular applicable to persons and organizations subject to the control of the AMMC.

- Banking Law (BAM) Dahir 1-14-193 carrying law 103.12 of December 24, 2014 relating to credit institutions and similar organizations

- Call for public generosity: Law No. 004-71 of October 12, 1971 on the calls for public generosity and Dahir No. 1-58376 of November 15, 1958 regulating the right of association, as amended and completed

- Exchange Regulations: General Instruction of Foreign Exchange Operations 
Table 4: Summary of regulatory obligations to different crowdfunding forms

\begin{tabular}{|c|c|c|c|}
\hline & Equity & Loan & Donation \\
\hline Text & $\begin{array}{l}\text { Dahir } 1-12-55 \\
\text { carrying law } N^{\circ} 44- \\
12 \text { of December } 28, \\
2012\end{array}$ & $\begin{array}{l}\text { Dahir } \quad 1-14-193 \\
\text { carrying law } 103.12 \text { of } \\
\text { December } 24,2014\end{array}$ & $\begin{array}{l}\text { Law No. 004-71 of } \\
\text { October } 12,1971\end{array}$ \\
\hline Regulation & $\begin{array}{l}\text { Law on the public } \\
\text { offering and the } \\
\text { information required } \\
\text { of legal entities and } \\
\text { organizations offering } \\
\text { public savings }\end{array}$ & $\begin{array}{l}\text { Law on Credit } \\
\text { Institutions and } \\
\text { Similar Organizations. } \\
\text { Said banking law }\end{array}$ & $\begin{array}{l}\text { Loi relative aux appels } \\
\text { à la générosité } \\
\text { publique et loi } \\
\text { réglementant le droit } \\
\text { des associations }\end{array}$ \\
\hline $\begin{array}{l}\text { Supervisory } \\
\text { Authority }\end{array}$ & $\begin{array}{l}\text { AMMC } \\
\text { Moroccan Capital } \\
\text { Markets Authority }\end{array}$ & $\begin{array}{l}\text { BAM } \\
\text { Bank Al Maghrib }\end{array}$ & $\begin{array}{l}\text { SGG } \\
\text { Secretary General of } \\
\text { the Government }\end{array}$ \\
\hline Common & \multicolumn{3}{|c|}{$\begin{array}{l}\text { Banking Law: Organizations assimilated to credit institutions designated } \\
\text { as payment institutions that have a monopoly on the collection and } \\
\text { preservation of funds and the management of the Electronic Money }\end{array}$} \\
\hline Common provisions & \multicolumn{3}{|c|}{$\begin{array}{l}\text { Exchange regulations: Obligation to declare transfers of MRE to the } \\
\text { customs services and justification of the origin of funds from the foreign } \\
\text { exchange office }\end{array}$} \\
\hline
\end{tabular}

Source: Developed by author based on different sources

It should be noted that in Morocco the term "crowdfunding" refers more to Islamic finance whereas crowdfunding is referred to as "collaborative financing".

\subsection{Banking Act}

The crowdfunding is in conflict with the monopolies provided by the banking law which prohibits any person, other than a credit institution previously approved by Bank Al Maghrib (BAM), to carry out credit operations as usual, to receive customary returnable funds from the public or to provide payment instruments that allow any person to transfer funds.

Article 1 of Law No. 103.12: Credit institutions are legal entities that carry out their activity in Morocco, regardless of the place of their registered office, the nationality of the contributors of their capital stock or their endowment or that of their leaders and who, as their usual profession, do one or more of the following activities:

- $\quad$ Receipt of public funds ;

- Credit operations ;

- Making available to customers all means of payment, or their management.

\section{a. Receiving public funds}

The activity of a platform is schematized by a set of cash flows (reception, preservation, transmission, restitution ...) between several actors. Whether it is the model of donation, loan or equity, all forms of crowdfunding are concerned by the monopoly of payment services reserved for payment institutions.

The banking monopoly prohibits anyone other than a credit institution previously approved by Bank Al Maghrib from receiving ordinary repayable funds from the public. The collection and custody of funds and the use and management of the Electronic Money are reserved for credit institutions.

In Morocco the recent law 103-12, known as the banking law, introduced electronic money in the field of application of means of payment as well as a new category of organizations assimilated to credit institutions designated as payment institutions... These institutions, referred to in Article 16 of the said law, are those that "offer one or more payment services and may also, in accordance with the laws and regulations in force, carry out the foreign exchange transactions". The fund transfer intermediaries are only authorized in Morocco to receive and make available funds from abroad, subject to compliance with the exchange regulations. These transactions can only relate to transfers between individuals.

\section{b. Credit operations}


The monopoly of the banking sector prohibits anyone other than a credit institution approved by Bank Al Maghrib, to carry out credit operations as usual. These provisions mean that an individual would have the right to lend money for money, however, he or she is prohibited from doing so by normal means.

This monopoly is explained not only by the traditional power of its actors but also by the will of the public authorities to supervise this activity given the risks that it engenders by limiting its exercise to actors having the necessary means and making the monitored by a regulator. Banks thus have an undeniable competitive advantage: access to the file of payment incidents, a financial base that prevents payment defaults, a technical capacity that allows the processing of files by demanding all the guarantees prior to granting a credit. However, this system is itself a brake for a collaborative model where the project promoters do not necessarily have the capacity to present such guarantees (mortgage, surety, pledge, ...). Moreover, a crowdfunding campaign makes it possible to collect the funds more quickly than the processing of a credit file at the bank.

In order to adapt the existing legislative framework to crowdfunding, some obstacles have to be removed to allow individuals to play the role of a bank within limits bordered by thresholds. Individuals should be given the opportunity to provide interest-based loans, earmarked directly for business or individual projects, and thus be able to participate in the real economy without spending too much of their savings.

In addition, the activity of crowdlending platforms should be regulated in order to impose a rigorous control of selected projects in order to provide some protection to lenders against the risk of payment incidents or startup failures. In this crowdfunding model, the platform also plays an intermediary role between two co-contracting parties because the transaction must necessarily be formalized by a loan agreement between the lender and the borrower that defines the rights and obligations of each party.

\subsection{The public offering}

The public offering consists of one of the following transactions: the admission of a financial instrument (shares, bonds, etc.) to trading on a regulated market and the issue or sale of financial instruments in the public using direct or indirect canvassing or advertising, or through a financial intermediary. (Law 44-12).

Equity crowdfunding could be defined as a public offering through the internet, thus reaching a dispersed audience and mobilizing financial resources through canvassing. Crowdinvesting probably has the most complex legal characteristics given the regulation of financial transactions in Morocco.

According to this Moroccan definition, a crowdfunding platform would be assimilated to a financial intermediary and the project developer to a public issuer. The investor would be entitled to the regulated information prior to any investment. These aspects are the prerogatives of the Moroccan Capital Markets Authority (AMMC) which is responsible for protecting savings invested in financial instruments.

\section{a. The issuer: the project leader}

A public offering in Morocco involves the obligation to prepare an Information Note submitted for approval by the AMMC and entails obligations regarding occasional and periodic financial information.

Writing a briefing note is not only technically complicated, but it also represents a significant cost to a project leader who should be responsible for the services of a financial advisor and a financial advisor. Jural advisor. The obligation to publish this information document constitutes a major obstacle. Indeed, the means available to a project leader being often limited, it seems difficult to envisage that it can meet this type of costs.

In Morocco, the private placement procedure concerns companies that wish to carry out an issue or sale of securities to a limited number (less than 10) of qualified investors. It exempts the initiator of the information obligations subject to informing the AMMC of the nature and terms of the transaction and to send him a certain amount of information.

This exception, however, could hardly apply to crowdfunding since the investors who act on the platforms do not have the quality of qualified investors and that the restricted circle of investors is the opposite of the logic of the crowdfunding which seeks precisely to reach a large audience to finance a project.

Under these conditions, it seems impossible for a Moroccan entrepreneur wishing to issue financial securities on a platform to be able to escape the publication of the financial information required by the regulations. Therefore, there should be a derogation from this obligation for project holders who wish to finance themselves through crowdfunding. However, in order to preserve the investor's protection, the platform should be obliged to provide a minimum of information about the company carrying the project.

\section{b. The investor: The crowd and the protection of savings invested in action}

The crowdfunding allows the investor to become a shareholder of the company and by this status he holds legal rights (right to information, voting rights ...), financial rights (right to dividends, liquidation bonus ...), and a patrimonial right (the freedom to dispose of one's actions). The public offering of debt (bond issue) gives the investor a financial right (interest and repayment of capital) and a right to information through the mass of bondholders.

The investor, just like a consumer, has the right to a protection which is translated by the right to an exhaustive information so that it knows precisely where he places his savings and what he risks by mobilizing it on a project. 
An investor who buys shares or bonds on a platform risks the outright loss of the amount of his subscription and he must be aware of this. Although a relaxation of the rules related to mandatory financial information prior to the launch of a financial transaction is essential to the development of crowdfunding it should not weaken the position of the investor.

In countries where the model has already experienced some growth, the specialization of platforms in fact inspires some confidence in investors when dealing with a crowdfunding specialist in a specific area. This specialization suggests that the projects are chosen by experts in the field concerned and thus offer a certain guarantee of success. Moreover, the profile of the investor itself determines the choice of one platform over another, depending on the nature of the return on investment sought (traditional activity generating immediate income, profitable activity in the long term, investment productive heavy ...).

This observation proves that the education dimension of the investor is very important and that the adaptation of the regulation must take into account the profile of the Moroccan investor the acquisition of a stake in a company should be accompanied by an ability to assess the risk. but the Moroccan investor still needs to be sensitized and educated.

In Morocco, the level of financial education was the subject of a collective awareness that led to the creation in 2013 of the Moroccan Foundation for Financial Education (FMEF) initiated by BAM and bringing together several public and private actors. The foundation has initiated a series of actions aimed at financial inclusion through the information effort. As part of its strategic plan, it organizes campaigns to raise awareness of the various financial products and services, whatever their degree of sophistication.

Apart from the role that the FMEF can play in raising awareness, a Moroccan crowdfunding federation is being created and will soon be operational. Its first vocation will be to organize the sector and promote this new financial instrument.

\section{c. The financial intermediary: The platform}

Although the amounts invested are often small, crowdfunding is considered a risky investment. In the scheme of a crowdfunding operation, the investor being a novice and the project manager having little means, the role of the platform becomes predominant in terms of financial information.

In Morocco, it is the financial intermediaries that are authorized to execute transactions on financial instruments. Indeed, according to the provisions of Article 2 paragraph 5 of Law 44-12, Financial Intermediaries are brokerage firms, banks or any other institutions whose purpose is investment, management, or advice. in financial matters, the list of which is fixed by the Ministry of Finance on the proposal of the AMMC.

Considering the above definition, a platform that typically offers financial instruments to the public through the use of advertising or third-party execution or who seeks investors on behalf of the public. a contractor could integrate the list of financial intermediaries. The AMMC would therefore be the supervisory authority for equity crowdfunding platforms.

The Moroccan bill plans to require a certain amount of information that will have to be published on the website of the platform and in particular the obligation to:

- Have the necessary technical skills for this type of activity;

- Respect the ethical rules that are essential for establishing a climate of trust;

- Present clear and comprehensive information on the proposed projects and the risks to which the investor is exposed.

To these conditions of access to the exercise of the activity are added the rules of good conduct and the professional capacity of directors and managers of platforms. These aspects should be ensured by the mandatory membership of an association that will be responsible for ensuring that the leaders of the platforms have the necessary skills for the performance of their missions and the presumption of good faith associated with them. It is expected that the Moroccan Federation of crowdfunding will play this role, but it would be necessary that this "label" is clearly displayed on the site of the platform in order to install a climate of confidence essential to the credibility of the tool.

\subsection{Call for public generosity}

Only associations having their headquarters in Morocco and regularly constituted, have the right to appeal to the public generosity subject to justify an authorization issued by the General Secretariat of the Government (SGG) for each collection (Article 4 Law 004-71).

Associations recognized as being of public utility have the right to appeal to the donation without prior authorization and this, once a year and subject to making a declaration to the SGG at least 15 days before the event (Art 9 law regulating the law of associations)

The microcredit associations can resort to fundraising by appeal to the public generosity without prior authorization, however they are required to send the Ministry of Finance a statement on the conditions, circumstances and results of the collection. (Article 11 law 18-97).

In order to comply with the regulations, the Cotizi Moroccan platform dedicated to the collection of donations only offers projects carried by associations. At the end of the campaign, the association can only receive the amount of the collection if:

- It justifie an authorization for the collection of donations granted by the General Secretariat of the Government; 
- It does not collect the funds and mandates Cotizi.com to buy the products and services subject to the collection (with provision of a supporting invoice).

The French platform COFUNDY collects funds from Maghreb ethnic groups for projects in their respective countries. As the call for funds is made abroad, it escapes national regulations.

Moroccan regulation will necessarily facilitate these procedures and lift certain prohibitions to adapt to the particularity of crowdfunding platforms if it does not want to slow down their growth.

\section{CONCLUSION}

In terms of specific crowdfunding legislation, Morocco is lagging behind Europe and North America, but it has assets that will allow it to be one of the main leaders at the regional level. Given the popularity of this tool that offers promising potential, its growth would benefit from being supported by a secure regulation for all stakeholders.

Moroccan legislation should be inspired by best practices while adapting to the local context the bill should ideally combine the two dominant approaches including:

- Create a status for the platforms and impose an approval essential to the exercise of the activity

- $\quad$ Prohibit platforms from giving advice to limit conflicts of interest

- Establish levels of due diligence to provide investors with quality information

- Imposing a limit beyond which the raising of funds would be requalified in a public offering with the obligation to publish regulated information

- Set ceilings for investors to take into account the debt capacity to protect savings invested in financial instruments

- $\quad$ Require platforms to use an authorized payment provider to secure collections

- $\quad$ Create a Label to clearly identify approved platforms.

\section{BIBLIOGRAPHY}

1. Initiation to the basic concepts of Foresight; Pr Lotfi Bouzaïane and Pr Rim Mouelhi 2006

2. http//:www.cairn.info - Le Crowdfunding, une innovation pour financer le developpement du Maroc - Thameur 3. Hemdane 2016

3. //:www.imist.ma - Le Crowdfunding au Maroc: Modeles existants et perspectives de developpement ; Sanae RHABRA, Wafa GUEGUER 2015

4. http//:www.cairn.info - Le Crowdfunding et diasporas : le financement participatif vient-il remettre en cause les acteurs du financement diasporique - Cecile FONROUGE

5. http//:www.imist.ma - Le Crowdfunding Comme Levier De Financement Des Porteurs De Projets Marocains : Etat Des Lieux - Younes ETTAHRI - Abderrahim LAACHACH

6. https://search.proquest.com - Financing of innovation in Morocco: What future for the crowdfunding? - Tadjousti, Hind; Jamal, Zahi. 2018

7. http://hubafrica.co/

8. http//:www.migrationpolicy.org/research/associer-les-diasporas-au-d\%C3\% A9veloppement

9. http//:www.marocainsdumonde.gov.ma/

10. http//:www.fh2mre.ma/

11. http//:www.ccme.org.ma/fr/

12. http ://www.migration4development.org/en/node/46042

13. www.homestrings.com

14. www.kiva.org

15. www.narwi.com

16. http://www.guide $\square$ entreprise.org/fr/home.html

17. http://www.cofundy.com/

18. http://www.marocainsdumonde.gov.ma/sites/default/files/Fichiers/Pages/MRE-2015.pdf

19. http://cadmus.eui.eu/bitstream/handle/1814/41124/MPC_2016_05.pdf

20. http://documents.banquemondiale.org/curated/fr/780781468052821805/Project-Information-Document-Concept-

Stage-Piloting-Equity-Financing-for-SMEs-in-Morocco-P150928 